\title{
Correction to: Human tissue-specific MSCs demonstrate differential mitochondria transfer abilities that may determine their regenerative abilities
}

\author{
Swati Paliwal ${ }^{1,2}$, Rituparna Chaudhuri ${ }^{1}$, Anurag Agrawal ${ }^{3^{*}}$ and Sujata Mohanty ${ }^{1 *}$
}

\section{Correction to: Stem Cell Res Ther 2018;9:298. https://doi.org/10.1186/s13287-018-1012-0}

The original article [1] contains errors in Fig. 1. The authors noticed a potentially misleading aspect of the original article Fig. 1 where representative flow cytometry data for different panels were from different data sets and thus the gates were not in the same line. This may cause confusion to the readers who attempt to compare panels and, thus the amended Fig. 1 shown ahead represents data from a single data set that is suitable for between panel comparisons.

\footnotetext{
Author details

'Stem Cell Facility, DBT Centre of Excellence for Stem Cell Research, All India Institute of Medical Sciences, New Delhi 110029, India. ${ }^{2}$ Department of Bioscience and Biotechnology, Banasthali Vidyapith, Rajasthan 304022, India. ${ }^{3}$ Molecular Immunogenetics Laboratory and Centre of Excellence for Translational Research in Asthma \& Lung Disease, CSIR-Institute of Genomics and Integrative Biology, Mall Road, Delhi 110007, India.
}

Received: 15 July 2019 Revised: 15 July 2019

Accepted: 15 July 2019 Published online: 26 July 2019

\section{Reference}

1. Paliwal S, Chaudhuri R, Agrawal A, Mohanty S. Human tissue-specific MSCs demonstrate differential mitochondria transfer abilities that may determine their regenerative abilities. Stem Cell Res Ther. 2018;9:298. https://doi.org/1 0.1186/s13287-018-1012-0.

\footnotetext{
* Correspondence: a.agrawal@igib.in; drmohantysujata@gmail.com ${ }^{3}$ Molecular Immunogenetics Laboratory and Centre of Excellence for Translational Research in Asthma \& Lung Disease, CSIR-Institute of Genomics and Integrative Biology, Mall Road, Delhi 110007, India

'Stem Cell Facility, DBT Centre of Excellence for Stem Cell Research, All India Institute of Medical Sciences, New Delhi 110029, India

Full list of author information is available at the end of the article
}

(c) The Author(s). 2019 Open Access This article is distributed under the terms of the Creative Commons Attribution 4.0 International License (http://creativecommons.org/licenses/by/4.0/), which permits unrestricted use, distribution, and reproduction in any medium, provided you give appropriate credit to the original author(s) and the source, provide a link to the Creative Commons license, and indicate if changes were made. The Creative Commons Public Domain Dedication waiver (http://creativecommons.org/publicdomain/zero/1.0/) applies to the data made available in this article, unless otherwise stated. 
A

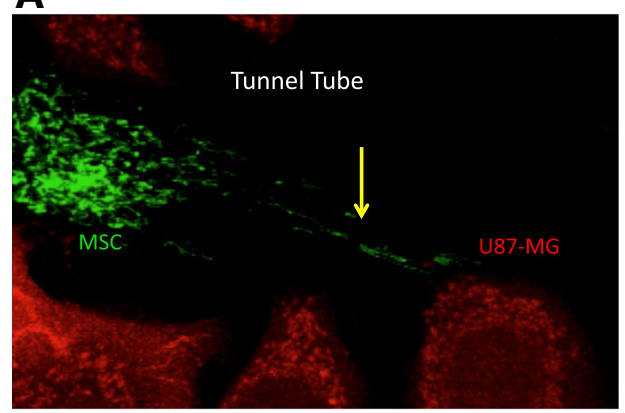

C (i) MSC alone (49.4\%)

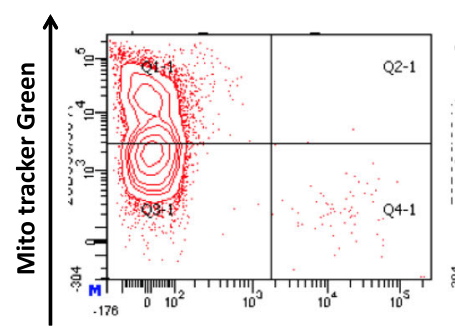

(ii) U87-MG alone (67.0\%)

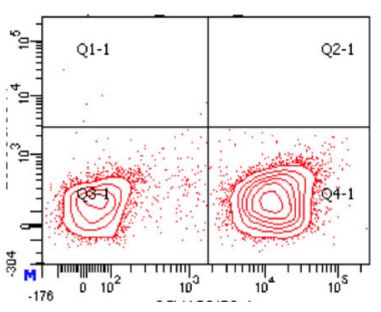

B

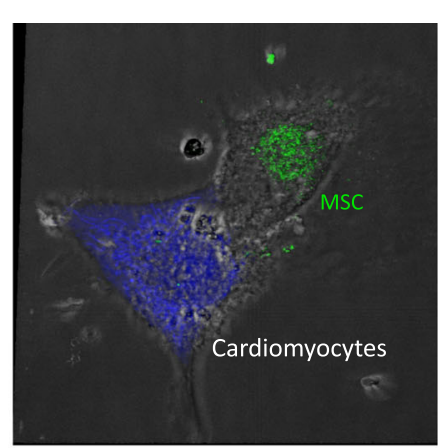

(iii) Co-culture MSCs and U87MG (Mito Transfer 34.9\%)

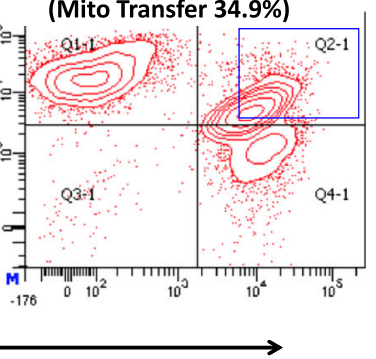

Cell Trace Violet

Fig. 1 Human mesenchymal stem cells (MSCs) can transfer mitochondria to U87-MG cells and rat cardiomyocytes. a Representative confocal images of mitochondrial transfer from bone marrow-MSCs (labeled with MitoTracker ${ }^{\circledR}$ Green) to U87-MG cells and (b) rat cardiomyocytes (labeled with Cell Trace Violet shown in red and violet, respectively). Scale bar $=20 \mu \mathrm{m}$. c A representative flow cytometric data plot shows the percentage of recipient U87-MG cells that take up mitochondria from BM-MSCs. The first plot shows cells stained with only mitotracker labeled MSC cells in Q1 quadrant, second plot shows only cell trace labeled recipient U87-MG cells in Q3 quadrant and third plot shows double positive U87-MG cells in Q2 quadrant 